\title{
'Articulating value' for clients in a global engineering consulting firm: "immaterial" activity and its implications for post-knowledge economy expertise
}

\begin{abstract}
Moulier Boutang's (2014) book Cognitive Capitalism introduces a radically different conception of the key resources - "immaterial labour" and "capture of externalities" for economic activity, compared with the argument in the knowledge economy discourse that professionals manipulate 'symbols.' The paper explores this claim by firstly, outlining the tenets of Moulier Boutang's argument and explaining why it introduces a new conception of value compared with how that concept is normally defined in neo-classic and Marxist economics. Secondly, explaining why client-facing project teams constitute a paradigmatic example of immaterial activity. Thirdly, makes visible the modes of activity which facilitate the capture of externalities by supplementing Moulier Boutang's concept with Boltanski and Thevénot's (2006) ideas about different economies or conceptions of worth. Case study evidence of a global engineering consulting company is then used to identify three expressions of immaterial
\end{abstract}


activity - educative', 'experimental' and 'entrepreneurial' - that assist engineers to articulate their value to clients. The paper concludes by arguing immaterial activity: (i) constitutes a form of expertise that is very different from the prevailing knowledge economy wisdom that knowledge workers manipulate symbols explicitly or tacitly; and, (ii) problematises the sui generis nature of the global 'employability' skills discourse.

Key words client-facing project teams, immaterial labour, expertise, innovation, situated judgement

\section{Introduction}

The shift from industrial to post-industrial or networked societies and knowledge economies has been extensively discussed for several decades in Social Theory (Bell 1973; Castells 2000; Stehr 2004, Thrift 2005), and the educational implications of that shift has also been extensively discussed in Education Studies (Brown and Lauder 1992; Brown et al. 2013; Daniels et al. 2010, Guile 2010; Livingstone and Guile 2013) Moulier Boutang's (2014) book Cognitive Capitalism introduces a radically different conception of the key resource for economic activity which has implications for both professional work, and the extent to which higher education can prepare individuals for certain forms 
of professional work. Moulier Boutang argues cognitive capitalism is concerned with the expenditure of "invention power: (Lazzarato) the living know-how which cannot be reduced to machines and the opinions shared in common by the greatest number of human beings" (Moulier Boutang 2011, 32). This constitutes a stage beyond the development of capitalist societies as knowledge or network societies and economies (see Vercellone et al. 2014 for an overview of the argument). That development rested on the assumption that science was the axial principle of economic development and, as a corollary, that higher levels of qualification were the proxy measure for human capital expert inputs into the knowledge economy (Guile 2010). Moreover, it gave rise to the idea that professional work involved the manipulation of symbols hence their description as "symbolic analysts" (Reich, 1992) or "knowledge workers" (Drucker, 1994). In contrast, Moulier Boutang (2011, 33 and 53) argues that the distinctive feature of cognitive capitalism is that work is increasingly organised in many sectors so professionals can work with one another for the "capture of externalities" within the work process (Moulier Boutang 2011, 22). Externalities are generated through “immaterial” activity (Moulier Boutang 2013, 31-33). This connotes 'work beyond work', in other words, professionals in the course of working together may generate ideas, data or knowledge based on a mix of their different expertise, which they may, on reflection, use to facilitate innovation in the form of new cultural content. Immaterial activity is 
therefore not a direct input into production because it "falls outside the economic" Moulier Boutang $(2011,22)$.

Moulier Boutang, in common with social theorists, focuses on the identification of trends within societies. As a consequence, he is unconcerned with, on the one hand, the processes professionals use to capture externalities or the way in which they justify different interpretations of possible courses of activity to one another and, on the other hand, the implications of his argument for professional formation, including 'skill' development in higher education. The aim of this paper is to address both issues. The paper argues the capture of externalities, which is a dialogic process because it is predicated on creating specific conditions for social cooperation at work, firstly, 'positions' (Hermans, 2012) professionals to articulate their value to one another as well as the client for whom they are working. Secondly, requires professionals to develop forms of situated expertise and judgement based on the commingling of the different insights that emerge while they are working together. To make visible the identification and justificatory practices professionals engage in to persuade clients to accept the merits of their suggestion, the paper draws on Boltanski and Thevénot's (2006) ideas about different economies or conceptions of worth. These conceptions were formulated by Boltanski and Thevénot to explore theoretically social interaction and the way in 
which individuals justify their interpretations to one another. We have "recontextualised" (Guile, 2010) Boltanski and Thevénot's conception of worth, as we explain below, as criteria to analyse the identification and justification of externalities.

To make this inter-connected argument, the paper firstly identifies the tenets that underpin Moulier Boutang's concept of cognitive capitalism and their implication for the organization of work. It then exemplifies the types of immaterial activity professionals engage in to articulate their value to clients by drawing on interviews from engineers, working for a global engineering consulting company. This type of company constitutes, as the paper explains below, a paradigmatic example of work organized in accordance with the principles of cognitive capitalism. The paper identifies three expressions of immaterial activity - the 'educative', the 'experimental' and the 'entrepreneurial' - that engineers engage in. It concludes by: that: (i) immaterial activity constitutes a form of expertise that is very different from the prevailing knowledge economy wisdom that knowledge workers manipulate symbols explicitly or tacitly; and, (ii) the emergence of immaterial expertise problematises the sui generis global 'employability' skills discourse.

\section{Cognitive division of labour and immaterial activity}


The concept of cognitive capitalism has been, as Wark $(2017,66)$ observes, "shaped by the Italian Autonomist tradition, .......and Marx's concept of the general intellect." The debate about the interplay between the post-Autonomist tradition and the general intellect has been characterised, according to Peters and Bulut $(2011, x i)$, by two main positions: some contributors adopt an "objectivist" position and accept Marx's conclusion that scientific and technological development in a capitalist economy will result in a dystopian future where machines replace labour or foresee a more utopian future where capitalism succumbs to its inherent contradictions and machine labour could be deployed to free humankind to realise its potential in ways other than through work (Scrnicek and Williams, 2005). In contrast, other contributors, including Moulier Boutang, follow Virno's (2004) very subtle interpretation of the general intellect and adopt a "subjectivist" position (Peters and Bulut, 2011, xi). This position is based on the premise that part of the general intellect does "...not congeal as fixed capital but unfold in communicative interaction, under the guise of epistemic paradigms, dialogical performances and linguistic games (Virno (2004, 65 italic in original)." In formulating this interpretation of the general intellect, Virno drew attention to the interplay between the technical, cultural and linguistic dimensions of work.

Moulier Boutang $(2012,32)$ however gives a distinctive twist to this subjectivist conception of the general intellect and accepts that the "essential point of capitalism is 
no longer the expenditure of human labour power, but that of invention power". While accepting that there will still be national systems of innovation and firms will still invest in research and development (R\&D), Moulier Boutang argues that what is equally important is the type of innovation that can occur within work. This led him to firstly, follow Lazaratto (1996) and accept that activities which until the 1980s were not recognized as work such as defining and fixing cultural and artistic standards, fashions, tastes, and consumer norms, play a major part in facilitating indeterminant innovative outcomes (a classic example being a 'brand' or reputation, see Lury, 2004 for an interesting discussion) or innovations within a product or service range. Secondly, to go beyond Lazaratto and introduce a new conception of innovation based on the "capture of externalities", in other words, identifying how ideas, know how, data etc. generated at work might through social cooperation be converted into a resource to facilitate innovation in the future (Moulier Boutang, 2012). The prediction and actualization of aesthetic taste in the form of products or services as well as projections about future innovations are defined by Moulier Boutang (2012) as "immaterial labour". He employs this term to denote that the form of value associated with the capture of externalities is hard to pin down. This is because, in contradistinction to neo-classic and Marxist economics which define work as form of material production and value was being determined by the amount of labour time that went it making a product, brands or the 
potential for innovation rely on "things that are very difficult to price" because "the contours of labour are unclear" (Wark, 2017, 67), in other words, they lack a determinant outcome.

The reason immaterial activity has become more common in the global economy is that many firms have deployed the principles of the cognitive division to de-specialise and de-compartmentalise the Post-Fordist division of labour (Vercellone et al. 2014), most commonly through the creation of inter-professional project teams. Certainly, there have been precursors of this trend. The introduction of Post-Fordist principles of work reorganisation ushered in the use of project teams (see Midler, 1995 for the classic analysis of the introduction of project teams in advanced manufacturing). The aim of Post-Fordism was however to improve the functional co-ordination of, and collaboration between, specialists in different phases and stages of production (Hecksher and Adler 2006; Edmondson 2012). In contrast, the aim of the cognitive division of labour is to recognise that work is both a site of production and innovation, in the sense, of generating ideas, data and knowledge.

One consequence of the re-organisation of production around the circulation and flow of knowledge in project teams is that, according to, Moulier Boutang $(2014,22)$, this 
form presupposes social cooperation between team members. In making this argument, Moulier Boutang adds another dimension to Virno's subjectivist interpretation of cooperation. He defined it as materialising "when a conspicuous portion of individual work consists of developing, defining and intensifying cooperation itself" (Virno, 2004, 62). In cognitive capitalism, social cooperation materialises itself as the capture of externalities which, according to Moulier Boutang $(2011,22)$ constitutes the "principal trading good", in other words, the resource that enables members of project teams to firstly, work together effectively. Secondly, articulate their value to the client who commissioned their services and thereby enhance their reputation or to a client who might, in future, commission their services. In making this argument, Moulier Boutang points towards, as Wark $(2017,71)$ observes, a more complex way of understanding capital than exists in neo-classic or Marxist scholarship. In short, he is arguing that knowledge production in workplaces is the "very thing that accumulation aims at" and, as a consequence, "value production comes to depend on social cooperation and tacit knowledge". Intriguingly, Moulier Boutang $(2014,71)$ maintains this is not only a goal of capitalist, but also peer, production because both are looking to capture value from activities other than traditional forms of labour, for example, R\&D, or established costcutting mechanisms, such as economies of scale or outsourcing. Exploring this issue, however, falls outside the scope of this paper. 


\section{Immaterial activity and judgement: reconciling different conceptions of worth}

As an economist Moulier Boutang's primary concern is the outcome of productive activity and its implications for capital accumulation. It is therefore hardly surprising that he does not discuss the social practices which facilitate the capture of externalities and their use as a trading good. Given our intention is to use his ideas about immaterial activity - capture of externalities and trading goods - to explore the way in which engineers articulate their value to clients, it is necessary to supplement Moulier Boutang's conceptual repertoire.

From our perspective, Boltanski and Thevénot's book can be reinterpreted as offering a theoretical framework to analyse the outcomes of the capture of externalities and the ensuing judgements project teams make about courses of action or recommendations for action. This involves "recontextualising" (Guile, 2010) their original aim and setting it in another context. Fortunately, Boltanski and Thevénot $(2006,20)$ offered us a way to achieve this goal. They acknowledge that they engaged in a process of recontextualization, in their terms "extend and rework", by drawing inspiration from writers, such as Latour and Callon, Hirschmann and Ricoeur work on micro-level social interpretation of macro-level issues. Bearing this in mind, we have we reworked and 
delimited their different conceptions of worth or value and the type of judgement involved in doing so, to analyse immaterial activity. We have firstly, interpreted the logic of: market as price; inspiration as creativity; and, industry as methodological and technical efficiency. In doing so, we acknowledge that each was underpinned by different principles of agreement and that professional activity tended to be associated, primarily, with one of these conceptions. Secondly, recast their concept of "situated judgement" (Boltanski and Thevénot 2006), which was originally formulated to explain micro-level decisions in relation to macro-level problems, to explain how interprofessional project teams articulate their value to clients. Situated judgements, according to Boltanski and Thevénot 2006, 215) involve all parties contributing to a decision-making process to make "justifiable agreements despite the availability of multiple principles of agreement ...... without acknowledging a relativism of value." The reason they define situated judgement in this way is, as Boltanski and Thevénot (2006, 215) acknowledge, they feel it is important to preserve "uncertainty about people's actions ...in any model purporting to account for human behaviour." From their perspective, judgements are resolutions to uncertainty: hence their situated nature. This reflects, as we shall show below, the challenges that client-facing interprofessional teams face when making team-decisions. 


\section{Researching immaterial labour: context and method}

We shed light on the type of activity professionals engage in to capture externalities to articulate their value to clients, through reference to our current research in a professional services firm; a global consulting engineering company. This research is funded through a grant received by UCL - Institute of Education's Centre for Learning and Life Chances in Knowledge Economies and Societies (LLAKES) from the United Kingdom's Economic and Social Research Council. The aim of the research is to identify the interplay between working and learning in, what we define as, client-facing interprofessional teams. We were interested in this issue because, although there has been some research in Communication Studies, Organizational Studies and Workplace Learning on project teams (see inter alia. Daniels et al. 2009; Engeström, 2008; Empson et al. 2015; Treem and Leonardi, 2016), very little research has addressed the role of the client commissioning work involving project teams and how that dynamic influences the working-learning process and its implications for professional formation. What is distinctive about professional services firms compared with other types of private sector organisations, such as automobile, electronic and pharmaceutical firms is that they "specialize in offering their expertise to other firms or conglomerations of financiers and firms" (Von Nordenflycht, 2010, 157). Professional service firms are therefore 
positioned to "compete for contracts from clients", by tendering for new work or identifying ways to either secure "repeat contracts" (Maister, 1993, 5); both outcomes enhance their reputation and enable them to secure contracts from new clients. The outcome of the contracting process is the creation of client-facing interprofessional teams. Work is therefore organized in accordance with the principles of the cognitive division of labour since teams are committed to the traversalisation and circulation of knowledge to accomplish project goals and, in the process, identify ways to articulate their value to the client who commissioned their services.

The focus of our research is Dachell a prestigious, global consulting engineering firm that employs over 1500 professionals in offices across the world. Dachell defines two thirds of its employees as 'core' engineers: disciplines such as structural, mechanical and civil engineering that are fundamental to the design process at all stages during the life of a project; these types of engineers tend therefore to work on projects for sustained periods. The other third is defined as 'specialist' engineers: disciplines such as acoustics, fire and façades. They work on a considerable number of projects at once. Access to Dachell was negotiated following discussions with the Chief Executive, plus the two Directors responsible for acoustic and façade engineering of the London-based executive team, regarding the potential benefit to the company of research on the 
activities their staff working in client-facing interprofessional project teams, engage in to secure repeat or new contracts.

The discussion was guided by the following principle: Edward's (2010) interpretation of Leonte'v's (1978) concept "object of activity". From this perspective, the object denotes both the purpose of an activity and the problem space it may generate. Expressed in language that reflects both company and research interests, both parties had: (i) a common goal and problem - to identify how the dynamics of client-facing interprofessional activity contributed to successful outcomes within existing contracts and securing repeat or new contracts. The reason this issue was under-identified within Dachell is because, as Dirk, Chief Executive observed "...securing repeat or new contracts means members of the firm have to know how to articulate conceptions of 'worth' or 'value' that project team members and clients are prepared to accept." As Dirk and his colleagues acknowledged, articulating value or worth is a complex issue in general and in client-facing interprofessional teams in particular. This is because they are firstly, not straight forward measurements of benefits and costs expressed by price and therefore hard to quantify, as Treem (2012) has noted, in accordance with traditional objective criteria such as task performance or professional standing. Secondly, work practices are de-compartmentalised, often invisible, and it is therefore not always clear to Dachell's 
executive team how members of project teams reconciled different conceptions of worth and how reputations were enhanced and additional contracts secured.

The agreement reached with the members of Dachell's executive team was to conduct our investigation of interprofessional project work in three phases. The first phase was scene setting conversations with the executive team to discuss their experiences of articulating value to clients and their recollections of the resources that assisted them to do so. In the course of these interviews we agreed, collectively, to focus on specialist engineers, because engineers who were moving in and out of projects on a regular basis, might have interesting insights into the dynamics of project work and its outcomes. The second phase was a series of interviews with a limited number of engineers to identify, retrospectively, the way in which they contributed to creating the conditions for social cooperation in client-facing project teams, and the extent to which this resulted in enhanced professional reputations and the securing of repeat or new contracts: in our terms, the type of immaterial activity they engaged in to capture externalities. The third phase, which is still underway, is to supplement the insights gained from the interviews by undertaking an extended observation of an interprofessional project selected from Dachell's current project portfolio of work, as well as interviews with individual members of the team and the client. This paper focuses on phase one and two. 
Our sample consisted of acoustic, façade and fire engineers who met the following criteria: (i) at least ten years' experience; (ii) at least five years' experience working for another company prior to joining Dachell; and (iii) a mix of ethnic and gender backgrounds. A total of six engineers were interviewed. In addition, we interviewed the chief executive of a globally renowned architectural professional service firm who had extensive experience commissioning engineering companies, including Dachell, on behalf of the client who had commissioned his company, to work on projects. This offered a complementary perspective on the relationship between the commissioning process and the negotiation of the scope.

We used semi-structured interviews. Our approach was based on Eraut's (2007) concept of "elicitation", that is, a conversational-style interview where an interviewee is asked to reflect, retrospectively, on issues pertaining to the dynamics of client-facing interprofessional project work. We created a set of researcher-initiated questions (Phillips and Hardy 2002) to guide our conversations with our interviewees, to probe the different facets of the engineers' immaterial activity. Questions included, 'did you encounter challenges when working for and/or with....', 'how did you address those challenges', 'were there any un-anticipated benefits or spin-offs from doing so' etc. This 
approach provided an opportunity for interviewees to "occupy different positions" (Dreier, 2011, p. 32) and therefore disclose different aspects of their experiences of working in client-facing interprofessional project teams to accomplish their contribution to the scope and to articulate their value to their client. Moreover, following Kvale (1999), we recognised that interviews always remain a "co-construction" informed by researcher, participant, and interview context and, as such, we were careful about jumping to any immediate conclusions when reading the interview transcripts. To ensure this did not happen, the transcripts were read by both researchers to formulate "exploratory categorizations" of interviewees' recollections (Lindof and Taylor 2002). This reading revealed examples of engineers' immaterial activity, demonstrating the value of their expertise to other members of their project team as well as their client. We continually re-read the transcripts in keeping with Miles and Huberman's (1994) recommendations about the value of adopting an iterative stance vis-à-vis towards the examples of immaterial labour we had identified. All the interviews were digitally recorded and lasted in the region of one hour. Based on the above iterative categorization process, we identified three examples of the ways engineers articulated their value to clients through the creation of conditions for a) social cooperation in project teams, b) innovation within a project team and c) innovation beyond a project 
team. We defined the, respectively, as 'educative', 'experimental' and 'entrepreneurial' immaterial activity. We present each of these in turn below.

\section{Articulating value to clients: the role of immaterial labour}

Client-facing interprofessional project teams: setting the scene

The work Dachell undertakes on behalf of clients who have commissioned their services is organised in client-facing interprofessional project teams, which last for the life of a contract. Projects are broken down into stages known as the 'Plan of Work'. This is the work process that the Royal Institute of British Architects (RIBA), in consultation with other construction industry partners, has defined to support more complex projects organise and plan delivery. As many contemporary construction projects involve multiple firms to provide expertise of different elements of a build, the Plan of Work provides a central focus to organise this multifaceted form of working. Alongside the Plan of Work, the project team agree the scope. The scope's main function is to define the aesthetic and technical contribution each type of commissioned professional in the project team will make and the associated allocated cost. It is thus crucial for 
establishing how the parameters of the contract agreed with the client are distributed across the project team.

Client-facing interprofessional project teams often involve several subcontracted firms who may have never worked together before, to organize their work around processes of communication, negotiation and accomplishment to coordinate contributions and manage the budget. The specialist engineers whose work we focus on in this section of the article are responsible for a specific aspect of a building, such as the fire strategy, acoustic effects or the façade, working on multiple projects at once and dropping into them at the appropriate stage. One challenge for the specialist engineers is to 'get up to speed' on projects they join, to understand the shared decision-making history of the project, the clients' aims (often the architect) and how the rest of the project team, thus far, have sought to deliver this - a significant challenge if team members have not previously worked together:

Daniel (architect):...all of a sudden you're with two people that you've never met before and you're thinking 'oh OK, we'll see how this works'. But you can define roles and responsibilities and the scope allows you to form a professional relationship with whoever you're given... it's feasible to do it in a professional 
way...if you've not worked with them before knowing exactly what they're going to do and when they're going to do it, that's the thing.

To move beyond this point, teams have to create conditions for social cooperation among them and their client, and also to create the conditions to capture externalities, articulate value to the client, foster innovation, and secure repeat business. Creating conditions for social cooperation involves agreeing normative criteria to enable them to determine their contribution in relation one another. We describe below the three examples of immaterial activity - educative, experimental, and entrepreneurial - we have identified, outlining how they function as a principal trading good to support discussions with their client and other project team members of the merits of their suggestion and consolidate their professional reputation.

Educative Immaterial Activity: Creating Conditions for Social Co-operation

The role of the scope is, as we saw above, to define the aesthetic and technical contribution each type of commissioned professional in the project team will make and the associated allocated cost. Project teams, however, then have to create the conditions for not only the coordination of work, but also to assist them to justify their 
recommendations to one another as regards the best way to accomplish their contribution to the scope and, hopefully, to capture externalities. We illustrate below the creation of the conditions engineers, in this case a fire engineer, employ to explain and justify their proposed solutions to their client and other stakeholders.

William: Quite often you get challenged by the clients and the design team as to "do we really have to do that" ... what I find is that you need to use your experience and say "well previously we tried this and we didn't get it approved" or "when we saw that the building was opened and managed this was not a very good solution because this kept breaking down and it wasn't as robust as maybe this solution". So we kind of talk through the issue and try and let the client understand what the issues are and try and inform them to make a decision. But you need to have a lot of knowledge and understanding to be able to do that.

Offering justifications for engineering decisions is an 'educative' issue, as William goes on to explain.

William: But yeah, so quite often you've to educate [emphasis added] the client a little bit about the technical aspects of things, and it can be difficult ...you need 
to be able to present in a technical format to the design team, a different type of technical format for the approvers, and then a completely different technical format for the client.

The ability to represent the same information for different audiences in different ways to persuade them of the voracity of the recommendations is central for ensuring that clients, and other project team members understand the relationship between the original vision for the building, the representation of that vision in the architect's design and engineers' technical options. As William observes above, this justificatory process is nevertheless quite complex because engineers have to produce different versions of the same justification to respond to the starting points and concerns of different audiences, which flow from the audiences' different conceptions of value, utilising their knowledge of those different conceptions to this end.

This form of immaterial activity is an important part of the engineers' work. To formulate their justifications, engineers' have to engage with team members', including the client, collective attachments to different values, such as creativity, technical excellence, financial acumen. In doing so, engineers learn to vary the normative conventions they invoke when formulating justifications for different audiences: 
William: ...we do a separate report for building management... so they can understand how to manage their building....it wouldn't have the technical justifications, it would just say 'because of this and this' and then spell out in English what it means physically. .what they have to be careful of

It is through this way of working in project teams that provides an opportunity for engineers to:

William: .... kind of see the other sides of everyone's design...you get a much better understanding of how a building works and how all the designs ... how your design actually interacts with other people's agenda, other designers' agenda, constraints and requirements.

This example of educative immaterial activity highlights the extended range of communication to facilitate the degree of social cooperation within a client-facing interprofessional project team, required to realise an innovative design. The challenge for William was to demonstrate that his continuing commitment to original aesthetic inspiration for agreed technical features of the design to the client, as much as other 
stakeholders, yet persuade them to accept that the technical adjustments he was proposing and their financial implications are necessary. The capability to educate clients and stakeholders is, as William indicates above, learnt in situ by interacting with other people's agendas, constraints, requirements and conceptions of value:

William: .... Through on the job training really, project by project. You know you kind of realise what's important, as you go through the various stages of a project .....talking to other engineers and the client

Ultimately, though, it is opportunities to lead the educative process that develops the capability and confidence to vary explanations for different audiences.

\section{Experimental Immaterial Activity: Innovation within a Project}

For many building projects, particularly buildings which have to ascribe to certain external requirements and are built frequently, such as schools and hospitals, there are standard solutions to aspects such as fire safety and noise reduction. Sometimes, however, clients and team members' passion and creativity can lead both parties to want to be more experimental than standard design specifications. Clients' visions and 
aspirations for a building can also evolve as they participate in project team discussions. When such requests surface in the life of a project they can, as Julie, a fire engineer explains, initially appear impossible since the project team still has to work within financial limits of what they have been commissioned to provide, but such requests also provide an opportunity for engineers to exhibit their creativity to support innovation within a project..

Julie: ....so we have set sort of codes and things to adhere to, and then this guy over here might say 'well actually I want this'......they come up with these fantastic buildings that go and that go beyond the code..... So we're just there to make sure that they're not doing anything too insane and, you know they've got down to the basics, you need the $X$ amount of exits, you need the $X$ amount of stairs.....So yeah it's about letting them be as crazy as they possibly can - and that's why they come back to us.

The extent of experimenting with the building codes (i.e. specifications re designs, materials etc.) will have financial implications, as costing may have been agreed based on standard specifications being used (which would be quicker to model). Thus, irrespective as to who initially inspires a team to be more innovative in how they 
interpret the scope, the challenge for one set of team members is to persuade other team members who are operating with different conceptions of worth, about the benefits of the proposed innovation. In the above example, experimentation for engineers entailed firstly, thinking differently about how to interpret the building code in ways that they may have never previously been attempted or been attempted within their networks. Secondly, using that new interpretation as trading good to help to persuade other team members that it is possible to realise the new design.

One form of experimental immaterial activity engineers mentioned was capturing the sources of inspiration, which often arise through conversation and speculation in the course of working on a scope, and then using them as the principal trading good to facilitate innovation. A good illustration of this type of 'capture and trading' emerged from the work William, a façade engineer, undertook on the building of a hospice. At the outset, this project had put users, elderly people and their families, at the centre of the design. Nevertheless, despite this focus, the agreed design retained the traditional architectural features associated with a hospice, as William explains: 
William:...so part of the thing was to make sort of prescriptive goals, look for lots of protected corridors and lots of compartmentation and exits in lots of places, but ...that would lead to a design where you've got lots of enclosed spaces and lots of places that are just not very nice for family and for people who are there, and patients who are in that kind of environment.

In the course of the project, the project team began to articulate while working on their contributions to the scope aspirations to improve the quality of patients' lives. The momentum behind this aspiration increased, consequently, the team became interested in innovating by going beyond established technical and aesthetic practices for hospice design, in other words, creating new 'cultural content'. The internal trading among team members, inspired the team to recommend to their client they should:

William: ...kind of open it [hospice design] up and make it much more of a friendly environment to be in...

William's contribution to achieve this new cultural content was to experiment and reenvision the fire codes to support the creation of a more open plan design. William had to use the code therefore as an enabling rather than constraining resource, and without 
compromising the patients' safety should a fire break out, to contribute to the teams' reconfiguration of the accepted conventions of hospice design aesthetics:

William: ... fire was a big aspect of that, so we had to push the alternative solutions for that quite a lot and do a lot of modelling for example to get large open spaces.... we knew that we were trying to make a better building, a more functional building that would work better, rather than something that just complies blindly with some sort of code recommendations. So that can be inspiring too.

The process of experimentation William engaged in requires a more dynamic form of working that is hard to represent in the fixed reality of the scope. It occurred in the life of the project as a result of the team's collective passion to design a building that enhanced the quality of patients' lives who would be living in the hospice, and to use that passion as an internal trading good among themselves and, ultimately, with their client. The shared normative criteria guiding team members' judgement about how to reconfigure the hospice design, which emerged as they commingled creative, technical and financial considerations in new ways, provided the team with an opportunity to innovate aesthetically and technically to create new cultural content. In doing so, the 
team enhanced their respective professional reputations and, as Julie acknowledged above, increased the likelihood that a client 'comes back to them' and they secure a repeat contract.

Entrepreneurial Immaterial Activity: Innovation Beyond a Project

Project work can also result in unforeseen developments that were not anticipated in the scope that requires more thinking, discussion and work time; in short, some branching out beyond the scope which may, in turn, result in innovation beyond a project. This type of development is not always predictable at the outset, as Oscar, a facades engineer, explains:

Oscar: ...Now on a project level I don't think it is predictable. When you get a project with certain architects you know that you're going to be pushed to innovate, but it's very difficult to predict on a project level. Sometimes it is the client who wants an inspirational building, right, so you know from the start that you are going to be pushed to find a special solution because the client wants a special building, whether it's from a sustainability point of view, whether it's from a visual point of view, but it's quite difficult to predict at a project level. 
On the other hand, clients' aspirations for a building sometimes positions engineers to be entrepreneurial if they are to support those aspirations and, in the process, enhance their own and their firms' reputation. This branching out may involve an engineer researching and developing new solutions, rather than repurposing knowledge, or educating clients about new materials were essential to realising their aspirations for their design. Sarah, a facades engineer, describes a new project she had recently started, which will not be built for 5 or 6 years, where the client wanted to create new, rather than accept, existing standards for environmental sustainability.

Sarah: ... the targets they've set in terms of like the environmental performance, sort of zero carbon, and using very energy efficient solutions and renewable energy and all that sort of thing are incredibly difficult, to the point where I don't think any of our existing technologies and systems we have can work. So we're really having to think outside the box, and think 'where can we put...where's the market heading....where can we push....where can we innovate' whilst always having this sort of maximum budget that we have, you know, not going too crazy.

This set Sarah a conundrum. She had to explain to her client why existing façade products were inappropriate for their needs: 
Sarah: ...we are trying to rule out everything that exists at the moment, or everything we know about, proving that it doesn't work......

Concurrently, she had to act entrepreneurially by talking to façade manufacturers about her client's aspirations for the building. Listening to their plans to develop their current range of products and suggesting how modifications to their plans would meet the needs of her client. She was, in other words, using her clients' aspiration to create new standards for environmental sustainability as the trading good to persuade a supplier to innovate within their product range:

Sarah:....talking to suppliers, we have quite a good relationship with a lot of European façade contractors....and they are developing little systems that we don't yet know about, sort of talking to them about what they're thinking of doing....and also telling them what our demands are helps them think about what they need to try to work on.... so this project particularly we have a very small amount of space in the façade and telling them 'we're thinking about doing this" and has been sort of where we are so far..... 
Striking a balance between respecting the confidentiality the client has invested in her, a desire to identify products that will satisfy the client's future need, and respecting the integrity of the procurement process is very tricky, as Sarah acknowledges:

Sarah: ...sort of trying to get information out of them without giving too much back is a bit of a challenge...

The above illustration of entrepreneurial immaterial activity draws attention to the complexity of an engineers' role in client-facing interprofessional project teams. There are multiple dimensions to the work they do concurrently in articulating their value to clients. In Sarah's case, she had to firstly, engage in educative immaterial activity to persuade her client to accept her advice that the current range of products would not enable them to realise their ecologically sustainable vision. Secondly, engage in entrepreneurial activity to persuade a potential supplier to customise one of their products (construction materials) to put them in a position where they might secure a contract in the future. The project scope would have included the need for Sarah to identify appropriate materials for the façade in line with the brief, but the consultations with manufacturers and ongoing discussions with the client go beyond this expectation and form what we identify as entrepreneurial immaterial activity: resulting in innovation 
beyond the project. To create the conditions to, potentially, realise this possibility, Sarah commingled different types of justifications for the courses of action she was recommending: for her client, presenting an argument about the limitations of the current state of fabrication in the market; and, for her manufacturer, inspiring them to innovate in anticipation of securing a down-stream contract.

\section{Immaterial expertise: an emerging conception of professional expertise?}

We have explained in the paper how work in some sectors of the global economy has been reorganised and rearranged in accordance with the principles associated with Moulier Boutang's concept of the cognitive division of labour, and shown why professional service firms are paradigmatic example of this trend. One feature of the reorganisation of work is the creation of interprofessional project teams to deliver contracts firms have secured from clients. To achieve this goal, it is necessary for project teams to foster forms of social cooperation among team members to facilitate, on the one hand, the transveralisation and circulation of knowledge among team members to ensure project goals are accomplished effectively; and, on the other hand, develop modes of activity to capture externalities which they can subsequently use to articulate their value to clients and secure repeat or new contracts. The capture of externalities, 
as we saw above, involves project team members firstly, identifying opportunities to be innovative, commingling their professional forms of knowing to actualise that opportunity in the form of an innovation within or beyond a project and, persuading a client about the potential benefit of either type of innovation. Secondly, reaching situated judgements, based on justifiable agreements, despite the availability of multiple principles of agreement, which they could accept among themselves as the best course of action before presenting those judgements to their client.

To form such judgements, it is necessary for client-facing interprofessional project teams to accommodate concerns and preoccupations that stem from different worlds or conceptions of worth alongside one another in relation to a current or prospective project. This requires team members to overcome the fragility, in the sense of endless discussion about different options, associated with the commingling of different conceptions of value. Project teams are however positioned to continually address and resolve this challenge, as we saw above, in two ways. The first is that the emphasis on social cooperation within the division of labour leads team members to accept that creative and aesthetic, technical and financial concerns are all endowed with their own identity, which the team will need to deploy in the service of a project goal. It also leads teams to accept, even if they have to continually renegotiate or from time to time or 
defer to whoever is leading on a specific aspect of the scope, their overarching goal would potentially fall apart if one or more of the elements were removed. For this reason, each team member is committed - contractually and motivationally - to finding a common justification to ensure a successful outcome.

It is our contention that the modes of immaterial activity we have identified engineers employ to reach situated judgement and articulate their value to clients, which we have defined as the:

- creation of social cooperation within teams

- capture of externalities

- formation of situated judgements and the avoidance of fragility

- use of externalities and judgements as a trading good

constitutes a new form of expertise: immaterial expertise.

Clearly, there is a symbolic dimension to this mode of expertise, because externalities are ideas, suggestions, visions etc. that can be deployed by project teams or their clients as resources to facilitate innovation. This symbolic dimension is, however, radically different from Reich's (1974) famous depiction of knowledge workers as symbolic 
analysts, which has cast a very influential shadow over debates about the knowledge economy in debates about education and work (see inter alia. Brown et al. 2011; Brown and Hesketh, 2004; Daniels et al. 2010, Guile 2010), or even Drucker's (2004) extension of that argument through his claim that 'all' forms of knowledge (theoretical, practical and tacit) are key resources in a knowledge economy. The term symbolic analyst referred to professionals or knowledge workers in functionally coordinated teams applying, manipulating or translating either the domain knowledge they had acquired from study in higher education or the workplace manifestations of that knowledge to support or enhance a given mode of production. This concept has had a powerful appeal to policymakers (OECD, 2001): it not only affirmed the value of the knowledge obtained in higher education to the development of the knowledge economy, but was also susceptible to being recast as description of the competences or skills that could be developed in higher education to support graduate employability.

In contrast, the capture of externalities and the formation of situated judgements has a less determinate and more hybrid symbolic dimension than knowledge application or manipulation. This symbolic dimension emerges as client-facing interprofessional teams work together to capture externalities and use them as a trading good to innovate within or beyond a project. For example, the passion to redesign the agreed design for the 
hospice arose within the flux of member of the project team working together. Symbolically, the concept of a hospice may have set a parameter for the redesign; however, the formulation and realisation of the new design emerged as team members reconciled their different conceptions of worth and value in relation to a new shared goal and a hybrid solution to realise that goal. This type of immaterial activity is more or less impossible to replicate in an educational context, because it presupposes a client who has commissioned the creation of a product or service and teams capturing and trading externalities. For this reason, we conclude that immaterial activity necessitates a form of situated expertise that can only be developed in client-facing interprofessional project teams. In making this case we are, in addition, making a post-Lave and Wenger situated argument which rests on a nuanced, and context-specific, set of assumptions about the relationship between the knowledge obtained in a degree, work and expertise. In the case of consulting engineers, the knowledge they developed in their degree constitutes only one element of the expertise they require to: create social cooperation within teams; capture externalities; formation of situated judgements; and, use externalities and judgements as a trading good. The other elements arise from within the cognitive division of labour that constitutes both their work context and therefore the context for their professional formation. 


\section{Conclusion}

The paper has argued that Moulier Boutang's (2014) book Cognitive Capitalism introduces a radically different conception of the key resource - immaterial activity for economic activity in some sectors of the global economy, and this constitutes a stage of economic development, beyond that previously denoted by terms, such as postindustrial societies and knowledge economies. The paper argued that client-facing interprofessional teams constitute the paradigmatic context for immaterial activity, and identified three expressions of that activity - the educative, experimental and entrepreneurial - the type of innovative outcome associated with each expression. The paper also argued that each expression presupposed that members of client-facing interprofessional teams worked together to create the conditions for social cooperation within teams, capture externalities, form situated judgements and to use externalities and judgements as a trading good among themselves and their clients. The paper concluded that the above four modes of activity constitute a new form of expertise immaterial expertise - which is very different from the prevailing knowledge economy wisdom that knowledge workers manipulate symbols explicitly or tacitly and, as such, problematises the sui generis global 'employability' skills discourse. 


\section{Funding}

This project was funded by a grant from the United Kingdom's Economic and Social Research Council as part of the UCL Institute of Education's Centre for Learning and Life Chances in Knowledge Economies and Societies (LLAKES).

The authors would like to thank the editor and reviewer one for their extremely insightful comments on an earlier version of this article which helped us to further clarify our argument.

\section{References}

Bell, D. 1976. The Coming of the Post-Industrial Society: A Social Venture in Forecasting. New York: Basic Books. 
Boltanski, L. and Thévenot, L. 2006. On Justification: Economies of Worth, tr. C. Porter. Princeton: Princeton University Press.

Brown, P. and Lauder, H. 1992. Education for Economic Survival: From Fordism to PostFordism London: Routledge.

Brown, P. Green, A, and Lauder, H. (1992) High Skills: Globalization, Competitiveness and Skill Formation. Oxford: Oxford University Press.

Brown, P. and Hesketh, A. (2004) The Mismanagement of Talent. Oxford: Oxford University Press.

Brown, P. Lauder, H. and Ashton, D. 2011. The Global Auction: The Broken promise of Education, Jobs and Income. Oxford University Press: Oxford.

Castells, M. 2009. The Rise of the Networked Society: Information Age, Economy, Society and Culture. Volume 1. Revised Edition. Chichester: Wiley-Blackwell. 
Corbin J and Strauss A. 2008. Basics of Qualitative Analysis: Techniques and Procedures for Developing Grounded Theory. Thousand Oaks, CA: Sage.

Crouch, C. Finegold, D. and Sako, M. 1999. Are Skills the Answer? The Political Economy of Skill Creation in Advanced Industrial Societies. Oxford: Oxford University Press.

Lauder, H. Daniels, H. Young, M. Ballarin, M. and Lowe, J. Eds. 2012. Educating for the Knowledge Economy: Critical Perspectives. London: Routledge.

Edwards, A., Daniels, H., Gallagher, T., Leadbetter, J., \& Warmington, P. (2009). Improving inter-professional collaborations: Multi-agency working for children's wellbeing. London: Routledge

Dreier, O. 2011. Psychotherapy in Everyday Life. Cambridge: Cambridge University Press.

Drucker, P, (1993) Post-capitalist Society: New York: HarperCollins.

Edmondson, A. 2012. Teaming: How Organizations Learn to Compete and Innovate in the Knowledge Economy. San Francisco: Jossey Bass. 
Edwards, A. 2010. Being an Expert Professional Practitioner: The Relational Turn in Expertise. Dordecht: Springer.

Engeström, Y. 2008. Knotworking: From Teams to Knots. Cambridge: Cambridge University Press.

Empson, L. Muzio, D. Broschak, J. and Hinings, B. (2015) The Oxford Handbook of Professional Service Firms. Oxford. Oxford University Press.

Eraut, M. 2007. "Learning from other people in the workplace". Oxford Review of Education. Vol 33(4): pp. 403-22.

Guile, D. 2010. The Learning Challenge of the Knowledge Economy. Rotterdam: Sense Publishers.

Hermans, H. and Hermans-Konopka. A. (2012) Dialogical Self Theory: Positioning and Counter-Positioning in a Globalising Society. Cambridge: Cambridge University Press. 
Kvale, S. 1999. Interviewing. London. Sage.

Lazzarato. M. 1996. 'Immaterial Labour'. In: Virno P and Hardt M (eds) Radical Thought in Italy: A Potential Politics. Minneapolis: University of Minnesota Press. Pp. 133-147.

Leotn'ev A.N. 1987. Activity, consciousness, and personality. Englewood Cliffs: PrenticeHall.

Lindlof, T. and Taylor, B. 2011. Qualitative Communication Research Methods. London: Sage.

Livingstone, D. and Guile, D. 2013. The Knowledge Economy and Lifelong Learning: A Critical Reader. Rotterdam: Sense.

Maister, D. 1993. Managing the Professional Service Firm. New York: Free Press.

Midler, C. (1995) “"Projectification”' of the Firm: the Renault case. Scandavian Journal of Management. 11 (4) 263-75. 
Miles, M.B. and Huberman, M. 1994. Qualitative Data Analysis. A Methods Sourcebook. London: Sage.

Moulier Boutang, Y. 2011. Cognitive Capitalism. Cambridge: Polity Press.

OECD (2001) http://www.oecd.org/innovation/research/1842070.pdf

Peters, M. and Marginson, S. 2008. Eds. Creativity and the Knowledge Economy. New York: Lang.

Peters, M. and Bulut, E. 2011. Cognitive Capitalism, Education and Digital Labour. New York: Lang.

Phillips N and Hardy C. 2002. Discourse Analysis: Investigating Processes of Social Construction. London: Sage.

Reich, R. (1991) The Work of Nations. Alfred. A. Knopf: New York.

Stehr, N. 1994. Knowledge Societies. London: Sage. 
Thrift, N. 2008. Knowing Capitalism. London: Sage.

Treem, J. 2012. “Communicating Expertise: Knowledge Performances in Professional Service Firms". Communication Monographs. Vol 79(1): 73-47.

Treem, J. and Leonardi, P. (2016) Expertise, Communication and Organizing. Oxford: Oxford University Press.

Van Nordenflycht, A. 2010. "Is a Professional Service Firm? Towards a Theory and Taxonomy of Knowledge-Intensive Firms". The Academy of Management Review. 35(1): 155-174.

Vercellone, C. (2007), "From Formal Subsumption to General Intellect: Elements for a Marxist Reading of the Hypothesis of Cognitive Capitalism", Historical Materialism, 15: $13-36$.

Vercellone, C., Monnier, J. M. Lucsarello, S. and Griziotti, G. (2014) Theoretical Framework on future knowledge-based economy. Available from: 
https://www.researchgate.net/publication/281600183 Theoretical Framework on $f$ uture knowledge-based economy [accessed Apr 26 2018].

Wark, M. 2017. General Intellects: Twenty One Thinkers for the Twenty-First Century. London: Verso. 